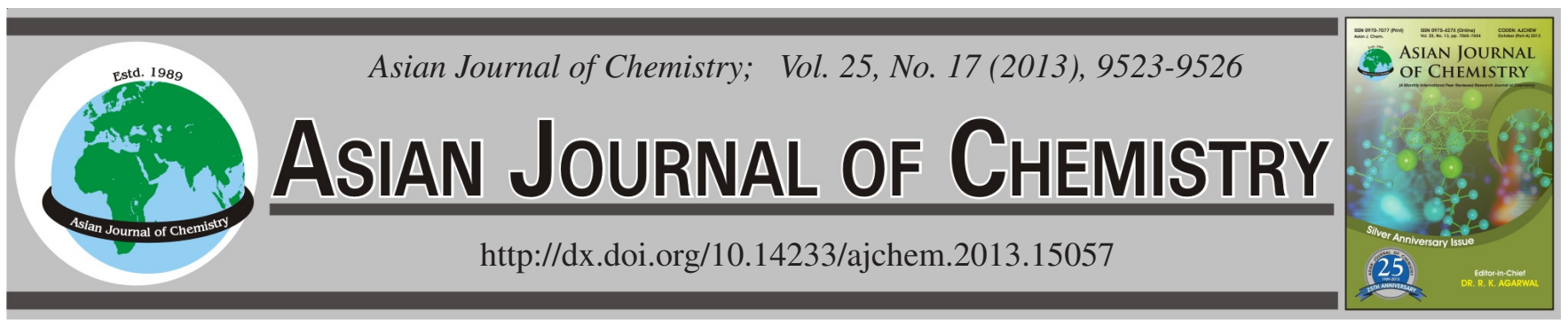

\title{
Investigation of Solid Waste Characterization, Composition and Generation Using Management of Environmental Systems in Zarqa, Jordan
}

\author{
Mohammad K. Younes ${ }^{1, *}$, Z.M. Nopiah ${ }^{1}$, B. NAdi ${ }^{1}$, N.E. Ahmad Basri ${ }^{1}$, \\ Hassan Basri $^{1}$, Mohammed F.M. Abushammala ${ }^{1}$ and Khaldoun Shatanawi ${ }^{2}$
}

\begin{abstract}
${ }^{1}$ Department of Civil and Structural Engineering, University Kebangsaan Malaysia 43600, Bangi, Selangor, Malaysia ${ }^{2}$ Department of Civil Engineering, University of Jordan, 11942 Amman, Jordan

*Corresponding author: Fax: +60 38 9215555; Tel: +60 18 3054435; E-mail: mohyoumoh@ @otmail.com
\end{abstract}

\begin{abstract}
Municipal solid waste management is a critical environmental challenge facing the development. Solid waste characteristics change with time due to changes in the population's consumption and lifestyle. Characterization of solid waste helps the decision makers take the sustainable actions. This is the first study that introduces integrated solid waste management principles in Zarqa, Jordan. The results indicate that the total solid waste generation is approximately 299 tons/day, with a generation rate of $0.69 \mathrm{~kg} / \mathrm{capita}$ per day. By 2030 , it is expected to reach 446 tons/day, with a generation rate of about $0.75 \mathrm{~kg} /$ capita per day. The organic fraction is $48.9 \%$, while the other main components like paper and cardboard and plastics are 13.3 and $15.2 \%$, respectively. The heat content is between 2,121 and 2,905 $\mathrm{kcal} / \mathrm{kg}$. A high organic content requires special considerations for waste handling and disposal. Moreover, it gives preference to composting over other heat recovery techniques.
\end{abstract}

Key Words: Solid waste management, Solid waste characterization, Solid waste generation.

ᄂ - - - - - - - - - - - - - - - - - - - - - - - - - - -

\section{INTRODUCTION}

The quality of the environment is an important determinant of human health. Most developing countries suffer from serious solid waste management (SWM) problems due to rapid population growth ${ }^{1-3}$. The generation of different quantities and qualities of solid waste is one of the most challenging problems that face current societies ${ }^{4}$. Solid waste generation is a natural outcome of human activities ${ }^{5}$. Selection of the proper systems by which to solve solid waste management problems is complicated due to the widely varied characteristics of waste, as well as the multiple criteria that need to be evaluated within such systems $^{6}$. The process of solid waste management is costly and time consuming, requiring the control of complex measures. For example, storage collection, transportation and disposal must be operated in accordance with the principles of public health and economics ${ }^{7}$. Improper solid waste management may lead to health problems, fire hazards, public nuisances and pollution of air, water and soil ${ }^{8,9}$.

In Jordan, the handling of solid waste is the responsibility of individual municipalities. Each municipality collects the solid waste then transports it to a transfer station or landfill for disposal. According to the Ministry of Environment (MoEnv), the average solid waste generation rate in Jordan is
$0.9 \mathrm{~kg}$ per capita per day and the total solid waste generation rate is about 5,500 tons per day. Additionally, although the percentage of solid waste collection from urban areas reaches $90 \%$, it reaches only $70 \%$ in rural areas ${ }^{10}$. Usually landfills are managed by an independent committee called the Common Council Services (CCS). Currently, there are 23 working landfills in Jordan. Municipal solid waste generation is increasing rapidly in Jordan due to population growth and unexpected migration to the region. Furthermore, urbanization plays a significant role in increasing solid waste generation rates and altering its composition, due to changes in lifestyle ${ }^{11}$. Table-1 shows the solid waste composition in Jordan as determined by previous studies ${ }^{10}$.

The city of Zarqa is considered to be one of the most environmentally unfriendly spots in Jordan due to the nature of activities within the city ${ }^{10}$. Over the last few decades, the development of the city has accelerated causing the population to grow dramatically and economical and industrial activities to increase significantly, thus seriously challenging the ability of local authorities to manage the generated waste. In general, the unplanned city expansion, caused by increased urbanization, is the major problem within the city. It hinders the achievement of sustainable development goals and strains the limited resources. The city generates industrial, agricultural, commercial, 
TABLE-1

WASTE COMPOSITION IN JORDAN

\begin{tabular}{lccccc}
\hline \multicolumn{1}{c}{ Study name } & MoEnv & JUST & CMCE & Fichtner & RSS \\
\hline Composition (\%) & 2009 & 2007 & 2002 & 1996 & 1994 \\
Organics & 38.8 & 52.2 & 51.4 & 44.0 & 53.0 \\
Paper and cardboard & 12.2 & 12.7 & 12.6 & 10.6 & 17.0 \\
Metals & 3.8 & 1.4 & 3.1 & 2.4 & 8.0 \\
Plastics & 17.1 & 17.1 & 14.2 & 13.2 & 12.0 \\
Glass & 2.6 & 2.5 & 1.8 & 1.4 & 10.0 \\
Textile & 8.5 & - & 4.2 & 4.7 & - \\
Rubber and leather & 1.5 & - & 3.0 & - & - \\
Hazardous waste & 0.1 & - & 0.1 & - & - \\
Miscellaneous & 15.4 & 14.1 & 9.6 & 23.6 & 0.0 \\
\hline
\end{tabular}

institutional and residential solid waste. Moreover, the bus stations in the city, which accommodate hundreds of thousands of passengers daily, generate additional waste. Finally, the solid waste generated at the Zarqa refugee camp must be transported to the transfer station by municipality vehicles.

The aim of the present study is to determine the characteristics of the solid waste generated by Zarqa, which will allow an integrated solid waste management system to be developed in the future. Solid waste sampling from the transfer station was conducted to estimate the composition, moisture and heat content of the waste.

\section{EXPERIMENTAL}

Study area: The municipality of Zarqa was established in 1928. Zarqa is one of the largest cities in Jordan according to the Department of Statistics ${ }^{12}$. The population of the city, as of 2010 , is $c a$. 470,760 people, while the area of Zarqa is approximately $65 \mathrm{~km}^{2}$. The climate is hot and dry during the summer and cool and rainy during the winter. The generated waste is transported to the transfer station, which is located to the southwest of the city, $12 \mathrm{~km}$ from the commercial center. The total area of the transfer station is $12,000 \mathrm{~m}^{2}$, but the used area is only $7,000 \mathrm{~m}^{2}$. The official working hours for the transfer station are from 7 am-11 pm, which requires two working shifts. For solid waste organizational purposes, the municipality was divided into nine districts with different population densities. Each district has one manager and a staff of supervisors and workers depending on its size and solid waste generation rate.

As with other cities in Jordan, machine maintenance shops are distributed all over Zarqa. In addition to the scattered main- tenance shops and workshops, there are six complexes distributed throughout the city where different activities are practiced like car maintenance, carpentry and steel forming. In general, there is no organized segregation for the solid waste, though a small portion of recyclables are collected by scavengers and sold to scrap yards.

General procedure: The data extend between the years 2010 and 2011. They include interviews with ministry of environment and municipality officers, questioners and field workers, as well as solid waste sampling at the transfer station. The sampling occurred between February and May of 2011. Samples of solid waste were collected from each city district. The waste composition was then determined using the quarter method. After determining the physical characteristics of the waste, including the composition, density, heat and moisture contents, the chemical compositions could be defined ${ }^{13-15}$.

Population and solid waste generation were estimated using the average of the constant rate $(2.2 \%)$, arithmetic, logarithmic, declining and S-curve methods ${ }^{16}$. These techniques were used due to the high differences in the population densities of the districts. As shown in Fig. 1, population density spreads from a high of 30,000 people per $\mathrm{km}^{2}$ in some districts to less than two hundred people per $\mathrm{km}^{2}$ in others.

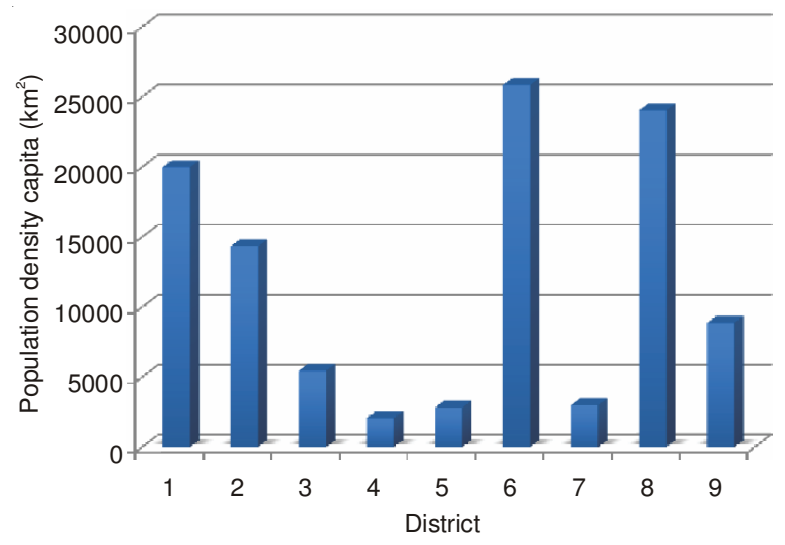

Fig. 1. Population density distribution in Zarqa

\section{RESULTS AND DISCUSSION}

Waste generation: Zarqa generates approximately 299 tons of solid waste daily, with a generation rate of approximately $0.69 \mathrm{~kg}$ per capita per day. This waste is transported to

\begin{tabular}{|c|c|c|}
\hline \multicolumn{3}{|c|}{$\begin{array}{c}\text { TABLE-2 } \\
\text { HEAT CONTENT ESTIMATION FORMULAS }\end{array}$} \\
\hline Physical composition analysis & Ultimate analysis & Proximate analysis \\
\hline Conventional model & Modified Dulong's Model & Traditional model \\
\hline $\begin{array}{l}\mathrm{H}_{\mathrm{n}}=88.2 \mathrm{R}+40.5(\mathrm{G}+\mathrm{P})-6 \mathrm{~W} \\
\mathrm{H}_{\mathrm{n}} \text { : net caloric value }(\mathrm{kcal} / \mathrm{kg}) \\
\mathrm{R}: \% \text { weight of plastic on dry base } \\
\mathrm{G}: \% \text { weight of garbage on dry base } \\
\mathrm{W}: \% \text { weight water on dry base } \\
\text { P: \% weight of paper on dry base }\end{array}$ & $\begin{array}{l}(\mathrm{HHV})=145 \mathrm{C}+610(\mathrm{H}-\mathrm{O} / 8)+40 \mathrm{~S}+10 \mathrm{~N} \\
\mathrm{HHV}: \text { High heating Value in }(\mathrm{Btu} / \mathrm{lb}) \\
\mathrm{C}: \text { is Carbon percentage } \\
\mathrm{H}: \text { is Hydrogen percentage } \\
\mathrm{O}: \text { is Oxygen percentage } \\
\mathrm{S}: \text { is Sulfur percentage } \\
\mathrm{N} \text { : is Nitrogen percentage }\end{array}$ & $\begin{array}{c}\mathrm{H}_{\mathrm{n}}=45 \mathrm{~B}-6 \mathrm{~W} \\
\text { B: combustible volatile matter } \\
\text { W: } \% \text { by weight of water on dry base }\end{array}$ \\
\hline $\begin{array}{l}\text { Kahn and Abu Ghrarah Model } \\
\mathrm{H}=23[\mathrm{~F}+3.6(\mathrm{PA})]+160(\mathrm{PL}) \\
\mathrm{H}: \text { heat content }(\mathrm{Btu} / \mathrm{lb}) \\
\text { F: } \% \text { of organic by weight } \\
\text { PA: } \% \text { of paper by weight } \\
\text { PL: \% of plastic by weight }\end{array}$ & $\begin{array}{l}\text { Dulong's model } \\
\mathrm{H}_{\mathrm{n}}=81 \mathrm{C}+34.2[\mathrm{H}-\mathrm{O} / 8]+22.5 \mathrm{~S}-6[9 \mathrm{H}+ \\
\mathrm{W}] \\
\mathrm{H}_{\mathrm{n}} \text { : net caloric value }(\mathrm{kcal} / \mathrm{kg}) \\
\mathrm{W} \text { : water, percent on dry basis }\end{array}$ & - \\
\hline
\end{tabular}


the transfer station, where a relatively ineffective manual recycling process is performed. About 8 tons of recyclables are collected daily. After recycling, the waste is sent to the Al-Gabawi landfill, which is located $37 \mathrm{~km}$ from the transfer station. Fig. 2 shows the monthly amount of solid waste transferred to the Al Gabawi landfill from the cities of Amman, Zarqa and Rusaifeh for the year of 2010. The monthly solid waste generation rate averages are 60,902, 8,805 and 5,142 tons, with daily generation rates of $c a$. 2,002, 291 and 169 tons for Amman, Zarqa and Rusaifeh, respectively. It is clear that during the summer period the solid waste generation increases due to the increase in tourists and the seasonal return of Jordanian expatriates.

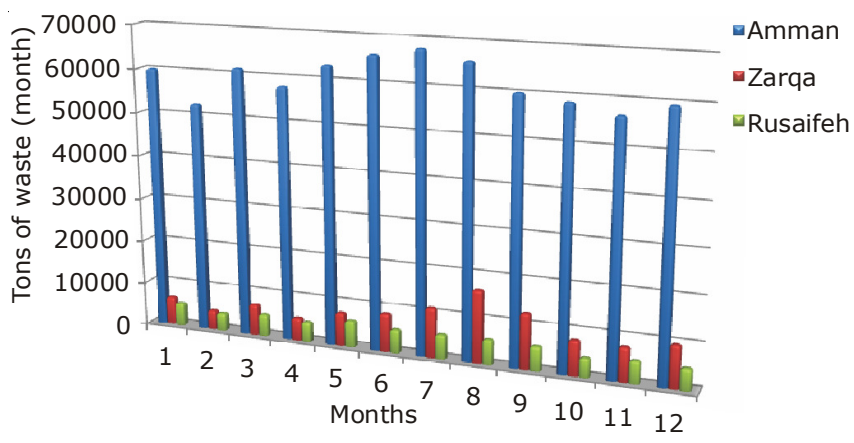

Fig. 2. Comparison of solid waste generation

The population is expected to reach about 597,000 people by 2030 , as shown in Table-3. Solid waste generation is expected to reach about 446 tons per day with a generation rate of about $0.75 \mathrm{~kg}$ per capita per day. Due to the absence of long term planning, the population is distributed unevenly over the nine districts, as shown in Fig. 1. This requires extra efforts to handle the generated solid waste in some overloaded districts.

Waste characteristics: The solid waste composition is summarized in Fig. 3. The organic fraction of solid waste in Zarqa is high compared to the average organic fraction for

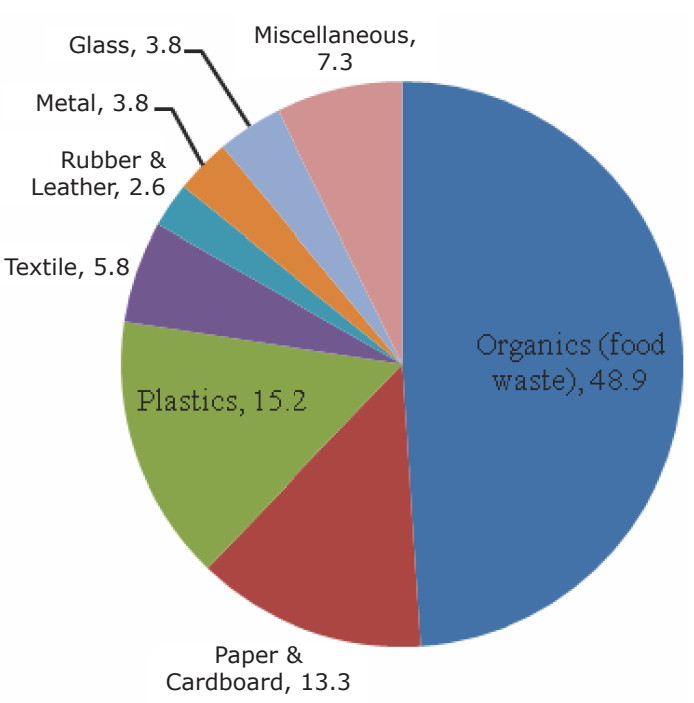

Fig. 3. Solid waste composition

Jordan, which is $38.8 \%$. This may be due to the high percentage of low-income families that live in Zarqa, who tend to produce a higher organic fraction and less packaging waste than the general population. The high organic fraction affects the average moisture content, which is $45 \%$. In addition, the recyclable fractions that are paper and cardboard, plastics and metals are close to the average values for the whole of Jordan. Although there is no official separation of recyclable items, part of these items are recovered by unofficial scavengers who sell to scrap yards or recycling plants. The density of the solid waste is $165 \mathrm{~kg} / \mathrm{m}^{3}$.

The heat content of the solid waste is between 2,121 and $2,905 \mathrm{kcal} / \mathrm{kg}$. Table- 4 shows the typical moisture and element contents based on the determined waste composition. The theoretical moisture content can be defined as the difference between the total organic fraction of solid waste and the total dry weight of the organic fraction. Because of the results in

TABLE-3

POPULATION AND SOLID WASTE FORECASTING FOR ZARQA FOR THE YEARS 2010-2030

\begin{tabular}{|c|c|c|c|c|c|c|c|}
\hline Year & $\begin{array}{l}2.2 \% \text { Annual } \\
\text { increment }\end{array}$ & $\begin{array}{c}\text { Geometric } \\
\text { method } \mathrm{k}_{\mathrm{g}}= \\
0.0259\end{array}$ & $\begin{array}{l}\text { Arithmetic } \\
\text { method } \\
\mathrm{k}_{\mathrm{a}}=88466\end{array}$ & $\begin{array}{c}\text { Declining rate } \\
\text { method } \mathrm{k}_{\mathrm{d}}= \\
0.6466\end{array}$ & $\begin{array}{l}\text { Long term } \\
\text { method } \\
\text { (S-curve) }\end{array}$ & $\begin{array}{c}\text { Average no of } \\
\text { population }\end{array}$ & $\begin{array}{c}\text { Expected SW } \\
\text { generation } \\
\text { (tons/day) }\end{array}$ \\
\hline 2010 & 470,763 & 470,763 & 470,763 & 470,763 & 470,763 & 470,000 & 299 \\
\hline 2015 & 480,340 & 535,022 & 512,333 & 486,862 & - & 503,640 & 368 \\
\hline 2020 & 490,907 & 609,040 & 554,667 & 499,067 & - & 538,420 & 400 \\
\hline 2025 & 501,707 & 693,298 & 597,000 & 507,901 & - & 574,977 & 428 \\
\hline 2030 & 512,745 & 789,212 & 639,333 & 514,295 & 529,828 & 597,083 & 446 \\
\hline
\end{tabular}

TABLE-4

SOLID WASTE COMPOSITION AND ITS ATOMIC VALUES REPRESENTATION

\begin{tabular}{|c|c|c|c|c|c|c|c|c|c|c|}
\hline \multirow{2}{*}{ Waste composition } & \multirow{2}{*}{$\begin{array}{c}\text { Solid waste } \\
\text { distribution }(\%)\end{array}$} & \multirow{2}{*}{$\begin{array}{c}\text { Typical } \\
\text { moisture (\%) }\end{array}$} & \multirow{2}{*}{$\begin{array}{c}\text { Dry } \\
\text { weight }\end{array}$} & \multicolumn{7}{|c|}{ Composition } \\
\hline & & & & $\mathrm{C}$ & $\mathrm{H}$ & $\mathrm{O}$ & $\mathrm{N}$ & $\mathrm{S}$ & Ash & Total \\
\hline Organics & 48.9 & 70 & 14.67 & 7.0 & 0.9 & 5.5 & 0.4 & 0.1 & 0.7 & 14.6 \\
\hline Paper and cardboard & 13.3 & 34 & 8.78 & 3.8 & 0.5 & 3.9 & 0.0 & 0.0 & 0.5 & 8.7 \\
\hline Plastics & 15.2 & 2 & 14.90 & 8.9 & 1.1 & 3.4 & - & - & 1.5 & 14.9 \\
\hline Textile & 5.8 & 10 & 5.22 & 2.9 & 0.3 & 1.6 & 0.2 & 0.0 & 0.1 & 5.1 \\
\hline Rubber and leather & 2.6 & 6 & 2.44 & 1.7 & 0.2 & 0.1 & 0.1 & 0.0 & 0.2 & 2.3 \\
\hline Metals & 3.1 & 2 & 3.04 & 0.1 & 0.0 & 0.1 & 0.0 & 0.0 & 2.7 & 2.9 \\
\hline Glass & 3.8 & 2 & 3.72 & 0.0 & 0.0 & 0.0 & 0.0 & 0.0 & 3.7 & 3.7 \\
\hline Miscellaneous & 7.3 & - & - & - & - & - & - & - & - & - \\
\hline Total weight of compostable fractions & 85.8 & - & 46.01 & 24.4 & 3.1 & 14.5 & 0.8 & 0.1 & 3.1 & - \\
\hline
\end{tabular}


TABLE-5

ATOMIC WEIGHT COMPOSITION AND MOLE FRACTION OF SOLID WASTE COMPONENTS

\begin{tabular}{cccccccc}
\hline \multirow{2}{*}{ Components } & \multicolumn{2}{c}{ Weight } & Atomic Weight & \multicolumn{2}{c}{ No of Moles } & \multicolumn{2}{c}{ Mole fraction } \\
\cline { 2 - 8 } & Without $\mathrm{H}_{2} \mathrm{O}$ & With $\mathrm{H}_{2} \mathrm{O}$ & & Without $\mathrm{H}_{2} \mathrm{O}$ & With $\mathrm{H}_{2} \mathrm{O}$ & Without $\mathrm{H}_{2} \mathrm{O}$ & With $\mathrm{H}_{2} \mathrm{O}$ \\
\hline Carbon & 24.355 & 24.355 & 12.100 & 2.013 & 2.013 & 670.936 & 670.936 \\
Hydrogen & 3.103 & 7.519 & 1.010 & 3.072 & 7.445 & 1023.945 & 2481.671 \\
Oxygen & 14.550 & 49.885 & 16.000 & 0.909 & 3.118 & 303.121 & 1039.273 \\
Nitrogen & 0.795 & 0.795 & 14.010 & 0.057 & 0.057 & 18.903 & 18.903 \\
Sulfur & 0.089 & 0.089 & 32.070 & 0.003 & 0.003 & 1.000 & 1.000 \\
Ash & 3.081 & 3.081 & - & - & - & - & - \\
\hline
\end{tabular}

Table-5, the suggested formula of the solid waste is as follows: Suggested formula of solid waste without water: $\mathrm{C}_{670.9} \mathrm{H}_{1023.9} \mathrm{O}_{303.1} \mathrm{~N}_{18.9} \mathrm{~S}$. Suggested formula of solid waste with water: $\mathrm{C}_{670.9} \mathrm{H}_{2481.7} \mathrm{O}_{1039.3} \mathrm{~N}_{18.9} \mathrm{~S}$.

Table- 6 shows the contribution of different elements to the solid waste. The formulas mentioned in Table- 2 are used to calculate the heat content ${ }^{15}$. The highest heat value (HHV) of energy content for the combustible fraction of solid waste, depending on the ultimate analysis, is: $(\mathrm{HHV})=145 \mathrm{C}+610(\mathrm{H}-$ $\mathrm{O} / 8)+40 \mathrm{~S}+10 \mathrm{~N}=5,235 \mathrm{Btu} / \mathrm{lb}=2,905 \mathrm{kcal} / \mathrm{kg}$.

\begin{tabular}{ccccc}
\multicolumn{5}{c}{ TABLE-6 } \\
\hline Component & $\begin{array}{c}\text { No of atom } \\
\text { per mole }\end{array}$ & $\begin{array}{c}\text { Atomic } \\
\text { weight }\end{array}$ & $\begin{array}{c}\text { Weight } \\
\text { contribution } \\
\text { of element }\end{array}$ & $\begin{array}{c}\text { Contribution } \\
\text { of element } \\
(\%)\end{array}$ \\
\hline Carbon & 670.9 & 12.1 & $8,118.3$ & 29.5 \\
Hydrogen & $2,481.7$ & 1.0 & $2,506.5$ & 9.1 \\
Oxygen & $1,039.3$ & 16.0 & $16,628.4$ & 60.4 \\
Nitrogen & 18.9 & 14.0 & 264.8 & 1.0 \\
Sulfur & 1.0 & 32.1 & 32.1 & 0.1 \\
Total & - & - & $27,550.2$ & 100 \\
\hline
\end{tabular}

The calculation for determining the heat content of the combustible fraction of solid waste, using the conventional model, is as follows:

$\mathrm{H}_{\mathrm{n}}=88.2 \mathrm{R}+40.5(\mathrm{G}+\mathrm{P})-6 \mathrm{~W}=2,310 \mathrm{kcal} / \mathrm{kg}=(4,157 \mathrm{Btu} / \mathrm{lb})$

The calculation of the heat content of the combustible fraction of solid waste, using the Dulong equation, is as follows: $\mathrm{H}_{\mathrm{n}}=81 \mathrm{C}+34.2[\mathrm{H}-\mathrm{O} / 8]+22.5 \mathrm{~S}-6[9 \mathrm{H}+\mathrm{W}]=$ $2,121 \mathrm{kcal} / \mathrm{kg}=(3,817 \mathrm{Btu} / \mathrm{lb})$.

The calculation of the heat content, using the Khan and Abu Ghrarah formula, is as follows: $\mathrm{H}=23\{\mathrm{~F}+3.6(\mathrm{PA})\}+$ $160(\mathrm{PL})=4,658 \mathrm{Btu} / \mathrm{lb}=2,585 \mathrm{kcal} / \mathrm{kg}$.

\section{Conclusion}

Solid waste characterization is very important for longterm sustainable development and planning. Domestic solid waste is the primary type of waste generated in Zarqa. As both the population and solid waste generation rate increase with time, the solid waste generation rate is expected to reach 446 tons/day by 2030, with a heat content ranging between 2,121 and $2,905 \mathrm{kcal} / \mathrm{kg}$. Current and future populations and solid waste generation rates are important factors for the sustainable planning of solid waste services. This information helps to properly design the required infrastructure to avoid future management problems.
The solid waste composition is the main factor in determining the solid waste treatment and investment alternatives. The high fraction of biodegradable waste in Zarqa requires special considerations regarding the solid waste collection, storage, treatment and disposal systems. For example, higher collection frequency is required to avoid odor and waste decomposition, while composting is highly recommended as the treatment choice. Moreover, the recyclable materials should be collected from the waste before its disposal, an area which requires further investigation to determine the best collection techniques.

\section{ACKNOWLEDGEMENTS}

The authors acknowledged the Zarqa municipality staff for their assistance with this research, especially Head of municipality council and Engineer Khaldoun Khasawnah.

\section{REFERENCES}

1. S. Suttibak and V. Nitivattananon, Resour. Conserv. Recycl., 53, 45 (2008).

2. M.R.A. Moghadam, N. Mokhtarani and B. Mokhtarani, Waste Manage., 29, 485 (2009).

3. N. Bilgehan, C. Tayfun, I. Fatih and B. Ali, Environ. Monit. Assess, 160, 491 (2010).

4. S. Elmira, N. Behzad, M. Mazlin Bin, K. Ibrahim and S.H. Halimaton, J. Public Health Epidemiol., 3, 54 (2011).

5. B. Nadi, A.R. Mahmud, A.R. Shariff and N. Ahmad, J. Environ. Sci. Eng., 3, 28 (2009).

6. B. Nadi, E. Shamshiry and A. Rodzi, Int. J. Chem. Eng. Appl., 2, 12 (2011).

7. T. Zamali, L.A. Mohd and M.T. Abu Osman, Matematika, 26, 1 (2010).

8. N.G. Turan, S. Çoruh, A. Akdemir and O.N. Ergun, Waste Manage., 29, 465 (2009).

9. S. Mor, K. Ravindra, A. De Visscher, R.P. Dahiya and A. Chandra, Sci. Total Environ., 371, 1 (2006).

10. Ministry of Environment, Report of Landfills Monitoring, Jordan (2009).

11. N. Al-Ansari, A. Al-Hanbali and R. Dhayaflah, Solid Waste Management and Disposal in Mafraq City. Institute of Earth and Environmental sciences, Al al-Bayt University, Mafraq, Jordan (2005).

12. Department of Statistics, Jordan in Figures, Jordan (2010).

13. G. Tchobanoglous, H. Theisen and S. Vigil, Integrated Solid Waste Management: Engineering Principles and Management Issues, McGraw-Hill, New York, USA, pp. 126-146 (1993).

14. S. Menikpura and B. Basnayake, Renew. Energy, 34, 1587 (2009).

15. M. Abu-Qudais and H.A. Abu-Qdais, Energy Conver. Manage., 41, 983 (2000).

16. W. Viessman Jr., M.J. Hammer and E.M. Pe, Water Supply and Pollution Control, Prentice Hall, pp. 92-94 (2008). 